\title{
Steroid Hormones Related to 11ß-hydroxysteroid Dehydrogenase Type 1 in Treated Obesity
}

\author{
L. MÁČOVÁ ${ }^{1}$, L. SOSVOROVÁ ${ }^{1}$, J. VÍTKƯ $^{1}$, M. BIČÍKOVÁ ${ }^{1}$, M. HILL ${ }^{1}$, \\ H. ZAMRAZILOVÁ ${ }^{1}$, B. SEDLÁČKOVÁ ${ }^{1}$, L. STÁRKA ${ }^{1}$ \\ ${ }^{1}$ Institute of Endocrinology, Prague, Czech Republic
}

Received May 18, 2015

Accepted June 1, 2015

\begin{abstract}
Summary
The local concentration of glucocorticoids is intensively regulated by $11 \beta$-hydroxysteroid dehydrogenase type 1 (11ß-HSD 1$)$. Human $11 \beta$-HSD 1 also reversibly catalyzes the inter-conversion of 7a-hydroxy- and 7 $\beta$-hydroxy-dehydroepiandrosterone (DHEA) into 7-oxo-DHEA. The cohort of 282 obese adolescents, 154 girls (median age 15.31 years, range 14.17-16.68 years) and 128 boys (median age 14.95 years, range 13.87-16.16 years), BMI (Body Mass Index) $>90^{\text {th }}$ percentile was examined. In samples collected before and after one month of reductive diet therapy, circulating levels of steroids were analyzed by liquid chromatography-tandem mass spectrometry and radioimmunoassay methods. The model of the treatment efficacy prediction was calculated. A significant reduction in circulating levels of cortisone, E2 and increased levels of 7 $\beta$-hydroxy-DHEA after the reductive treatment was observed. Levels of cortisol, DHEA, DHT sustained without any significant change. The predictive Orthogonal Projections to Latent Structures (OPLS) model explained $20.1 \%$ of variability of BMI, z-score change by the basal levels of 7a-hydroxy-DHEA, DHEA, cortisol and E2 as the strongest predictors. Reduced levels of circulating cortisone and reduced ratios of oxygenated/reduced metabolites reflect increased reductase activity of $11 \beta-H S D 1$ with reduced BMI, $z$-score. We hypothesize whether these changes can be attributed to the altered activity of 11ß-HSD 1 in the liver.
\end{abstract}

\section{Key words}

Steroids • Obesity $\bullet 11 \beta$-hydroxysteroid dehydrogenase type 1 • Glucocorticoids • Dehydroepiandrosterone

\section{Corresponding author}

L. Máčová, Department of Steroids and Proteofactors, Institute of Endocrinology, Národní 8, 11694 Prague 1, Czech Republic. Fax: +420224905 325. E-mail: Imacova@endo.cz

\section{Introduction}

According to the recent data of the World Obesity Federation, there are around 1.5 billion overweight adults and over 200 million overweight school-age children. This vast number of obese patients is now recognized as one of the most important public health problems.

It has been well documented, that steroid hormones, especially glucocorticoids (GC), are involved in maintaining energy balance. Its disruption may lead to obesity and metabolic syndrome, as seen in the condition of chronic stress (Rosmond 2005) and patients with Cushing's syndrome (Rebuffe-Scrive et al. 1988, Bista and Beck 2014). Indeed, in addition to effects on glucose metabolism (Schacke et al. 2002), GC increase serum levels of free fatty acids (Djurhuus et al. 2002), increase lipolysis (Tomlinson et al. 2007) and stimulate differentiation of adipocytes (Hauner et al. 1987). There has therefore been great interest in revealing the role of endogenous GC in the development of obesity.

The effect of GC depends not only on plasma levels, regulated through the hypothalamic-pituitaryadrenal axis, but also on intracellular levels, regulated by tissue specific enzymes. One of these enzymes, $11 \beta$-hydroxysteroid dehydrogenase type 1 (11 $\beta$-HSD 1) amplifies local GC action. This enzyme is responsible for the regeneration of cortisol from inert cortisone (Seckl and Walker 2001) and is present in various tissues including adipose tissue (Ricketts et al. 1998). Numerous papers report that the elevated expression and activity of adipose $11 \beta$-HSD 1 is linked to obesity and metabolic syndrome in humans (Rask et al. 2001, 2002, Kannisto et al. 2004, Valsamakis et al. 2004) as well as animals 
(Livingstone et al. 2000, Masuzaki et al. 2001). At the same time, Stimson et al. (2009) anticipate that a $10 \mathrm{~kg} / \mathrm{m}^{2}$ increase in BMI might elevate the whole-body adipose production of cortisol of $\sim 12.7 \mathrm{nmol} / \mathrm{min}$ (accounting for $\sim 15 \mathrm{~kg}$ increase in fat mass). Conversely, $11 \beta$-HSD 1 knockout mice have demonstrated an improved lipid profile, resistance to stress and obesityrelated hyperglycemia together with a reduced gluconeogenic response (Kotelevtsev et al. 1997, Morton et al. 2001). Nevertheless, the literature on the expression of $11 \beta$-HSD 1 in human obesity is discordant. Some studies found no significant difference in expression of adipose $11 \beta$-HSD 1 in obese vs. non-obese subjects (Tomlinson et al. 2002).

The specific inhibition of adipose $11 \beta$-HSD 1 provides a promising tool in the treatment of obesity. The most recent data of clinical studies with several selective 11 $\beta$-HSD 1 inhibitors have shown moderate body weight reduction as well as improvement in insulin sensitivity and hyperglycemia (Rosenstock et al. 2010, Feig et al. 2011, Gibbs et al. 2011, Shah et al. 2011, Anagnostis et al. 2013, Heise et al. 2014). However, these compounds have limitations and none of them provides overall protection from obesity and metabolic syndrome.

It is of interest that some endogenous steroids act as modulators of $11 \beta$-HSD 1 activity. The first of these are glucocorticoids employing $11 \beta$-HSD 1 for their metabolism. They also enable the stimulation of $11 \beta$-HSD 1 enzymatic activity as well as the expression of the enzyme (Hammami and Siiteri 1991, Bujalska et al. 2006, Zhu et al. 2010).

The sex steroids were intensively studied to explain gender different metabolism and body fat distribution. Only a few studies have examined the effect of sex steroids on $11 \beta$-HSD 1, but with controversial outcomes. Some studies have reported an inhibitory effect of $17 \beta$-estradiol (E2) in adipose tissue on mRNA, enzyme expression and enzymatic activity of $11 \beta$-HSD 1 (Hammami and Siiteri 1991, Gomez-Sanchez et al. 2003, Tagawa et al. 2009). Other authors (Andersson et al. 2010) observed the same effect in liver and visceral, but not in subcutaneous fat. These observations are in contrast with Dieudonné et al. (2006), who found E2 to be a strong up-regulator of $11 \beta$-HSD 1 mRNA expression in women's preadipocytes. In addition, androgens exhibit a significant stimulation effect on the $11 \beta$-HSD 1 activity and expression after the treatment with 5a-dihydrotestosterone (DHT) (Dieudonne et al. 2006) and testosterone (Liu et al. 1998). Nevertheless, the combined treatment of testosterone and cortisol did not increase the level of $11 \beta$-HSD 1 as seen with each steroid alone (Zhu et al. 2010).

Finally, there is a group of dehydroepiandrosterone (DHEA) and its metabolites that has been reported to regulate enzymatic activity of $11 \beta$-HSD 1. DHEA suppresses the expression and activity of $11 \beta$-HSD 1 in adipose tissue, which contributes to the clarification of the anti-obesity effect of DHEA (Apostolova et al. 2005, Tagawa et al. 2011). 7-hydroxy metabolites of DHEA, found in our laboratory as early as 50 years ago (Starka et al. 1962, Starka and Hampl 1964), have been over the past decade suggested as substrates for $11 \beta$-HSD 1 (Robinzon et al. 2003). Indeed, the enzyme $11 \beta$-HSD 1 reversibly catalyzes the conversion of $7 \alpha$-hydroxy- and $7 \beta$-hydroxy-DHEA into 7-oxo-DHEA (Muller et al. 2006b, Zhou et al. 2012), and both 7-hydroxylated metabolites of DHEA competitively inhibit cortisol oxidation (Hennebert et al. 2007). Moreover, DHEA itself as well as its 7-hydroxylated derivatives perform anti-GC effects (Chmielewski et al. 2000), which may be explained by the favored production of 7-hydroxy-DHEA over that of active glucocorticoids (Muller et al. 2006a).

Despite the fact that the GC excess is associated with central obesity and insulin resistance, the relationship between circulating cortisol levels and abdominal obesity has been highly inconsistent (Abraham et al. 2013). In order to contribute to the revelation the role of $11 \beta$-HSD 1 in obesity, we followed the alteration of circulating levels of steroids related to $11 \beta$-HSD 1 in patients treated for obesity.

\section{Materials and Methods}

\section{Subjects}

The cohort for the present study was recruited from the Childhood Obesity Prevalence and Treatment project; the epidemiological and intervention study evaluated the prevalence and treatment of obesity in children from the Czech Republic. A group of 282 obese patients, 154 girls (median age 15.31 years, range 14.17-16.68 years) and 128 boys (median age 14.95 years, range 13.87-16.16 years), BMI $>90^{\text {th }}$ percentile for age and sex of the Czech reference (Kobzova et al. 2004), was examined. Exclusion criteria were endocrine disorders including diabetes and use of drugs affecting body weight (glucocorticoids, psychotropic drugs, contraceptives, etc.). The hydration status and plasma 
protein of the subjects were normal.

The study protocol was approved by the Ethics Committee of the Institute of Endocrinology in Prague and was performed in accordance with the ethical standards of Helsinki Declaration II. and its later amendments. Written informed consent was obtained from all participants and their parents prior to their inclusion into the study.

All patients underwent reductive therapy that consisted of adjustment of energy intake and observance of physical activity. The weight management program was provided on an in-patient basis in a center specialized in weight management for children/adolescents within a period of 4 weeks and was strictly medically supervised (pediatricians, dietitians, physiotherapists, psychologists). Adolescents had aerobic exercise $3.5-4.0 \mathrm{~h}$ per day (e.g. jumping, jogging, ball games, fitness, swimming, dancing, and hiking 4-10 km/day). Screen time was limited to maximum of $1 \mathrm{~h}$ a day. The decreased daily energy intake (to 5-7 MJ/day) was individually modified according to age and BMI in order to ensure the recommended daily consumption of all essential nutrients and appropriate macronutrient balance. The intake of fat, protein and carbohydrates was aimed at $30 \%, 15-20 \%$ and $50-55 \%$ of energy intake, resp. sugar intake was $<5 \%$ of total energy intake. For more details see (Hlavaty et al. 2010).

\section{Anthropometric data}

Anthropometry was performed after $12 \mathrm{~h}$ of fasting on subjects dressed in their underwear. Height (to the nearest $0.5 \mathrm{~cm}$ ) was measured by a stadiometer, body weight (to the nearest $0.1 \mathrm{~kg}$ ) by Tanita BC-418 MA (Tanita Corporation, Tokyo, Japan). Body mass index (BMI) was calculated as weight $(\mathrm{kg})$ divided by the square of height $\left(\mathrm{m}^{2}\right)$. Each BMI was conversed to a BMI, z-score, which reflects the number of standard deviations that an individual subject deviates above or below the BMI mean matched with general Czech population (Kobzova et al. 2004) of the same gender and age.

\section{Chemicals and reagents}

Cortisol, cortisone and dehydroepiandrosterone (DHEA) were purchased form Koch-Light Laboratories LTD (Colnbrook, Great Britain), $7 \alpha-\mathrm{OH}-\mathrm{DHEA}, 7 \beta-\mathrm{OH}-$ DHEA, 7-oxo-DHEA, 16 $\alpha$-OH-DHEA and D3-DHEA were from Steraloids (Newport, USA). D4-Cortisol was from CDN isotopes (Ponte-Claire, Canada). 2-hydrazinopyridine, ammonium formate, methyl tertbutyl ether and trifluoroacetic acid were from SigmaAldrich (St. Louis, USA). LC-MS grade methanol, water and diethyl ether were from Merck AG (Darmstadt, Germany). The physiological solution $(0.9 \%$ sodium chloride) was from B-Braun (Melsungen $\mathrm{AG}$, Germany). [1,2,6,7-3H]Cortisol, specific radioactivity $3.04 \mathrm{TBq} / \mathrm{mmol}$ was from Amesrham Biosciences, Inc. (Amersham, UK).

\section{Hormonal analysis}

Hormonal analysis was performed on blood samples collected from fasting patients between 7:00 and 9:00 a.m. Plasma samples were stored at $-80^{\circ} \mathrm{C}$ in plastic tubes until laboratory processing.

LC-MS/MS analysis was performed using an API 3200 (AB Sciex, Concord, Canada) triple stage quadrupole - mass spectrometer with electrospray ionization connected to the UHPLC Eksigent ultraLC 110 system (Redwood City, CA, USA). Chromatographic separation was carried out on a Kinetex C18 $2.6 \mu \mathrm{m}$ $(150 \times 3.0 \mathrm{~mm})$ column (Phenomenex, Torrance, CA, USA) with a corresponding security guard. The CSF levels of cortisol, cortisone, DHEA, 7 $\alpha$-hydroxy-DHEA, 7 $\beta$-hydroxy-DHEA, 7-oxo-DHEA and 16 $\alpha$-hydroxyDHEA were measured by the method described elsewhere (Sosvorova et al. 2015).

DHT was assayed by the original radioimmunoassay (RIA) developed previously in the author's laboratory (Hampl et al. 1990). E2 was determined using the RIA kit (Orion Diagnostica, Espoo, Finland).

\section{Statistical analysis}

The differences $(\Delta)$ in values before and after the reducing treatment were calculated for each subject separately. The effects of gender and treatment on individual parameters were evaluated using ANOVA model with factors Gender, Age group and Gender $\times$ Age group interaction. Least significant multiple comparisons followed the ANOVA model. To attain data symmetry and constant variance, the original data was transformed by Box-Cox transformations. Statistical software Statgraphics Centurion v. XV from Statpoint (Herndon, VA, USA) was used for the analysis. The relationships between change of BMI, z-score on the one hand and basal BMI, z-score and steroid levels and ratios on the other hand, were evaluated using multivariate regression with a reduction of dimensionality (model of orthogonal 
projections to latent structures, OPLS). This approach allows for severe multicollinearity in the set of predictors to be coped with and also enabled the separation of variability shared between dependent variable and predictors from the variability shared within the matrix of predictors. As in the case of ANOVA testing, the original data was transformed to symmetry and homoscedasticity using the Box-Cox transformations.

\section{Results}

Significant decreases in BMI, z-score before and after treatment were found in all examined groups. The reductive therapy was the most effective in fourteen-yearold boys, whereas seventeen-year-old boys showed the smallest weight reduction after the reductive treatment (Fig. 1).

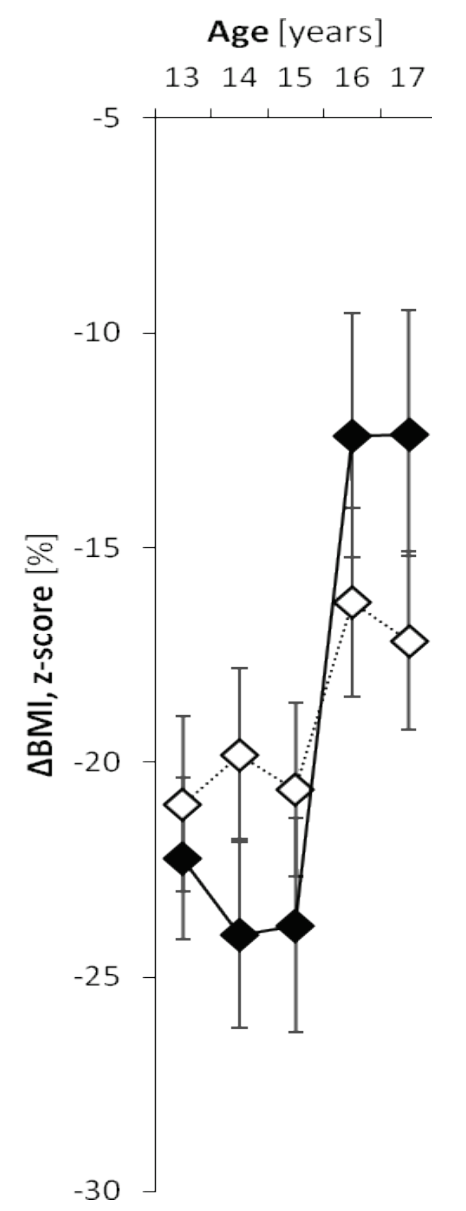

Fig. 1. The difference $(\Delta)$ of body mass index, $z$-score after the reductive treatment. The ANOVA model consisting of factors Gender and Age group and Gender $\times$ Age group interaction followed by least significant difference multiple comparison was used. The symbols with error bars represent the group means with their $95 \%$ confidence intervals. Black symbols mean males, white females. The significance of factors and interaction was as follows: Gender: $F=0, p=0.9675$; Age: $F=11.4, p<0.0001$; Gender $\times$ Age: $F=3, p=0.0198$.

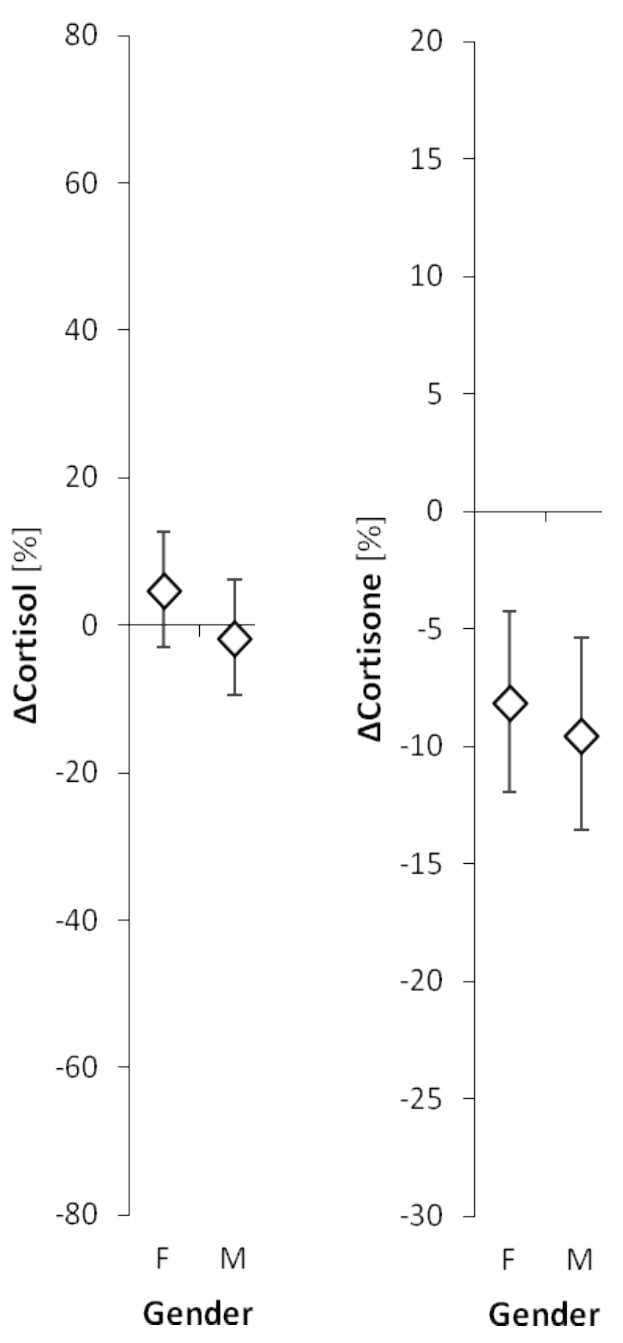

Fig. 2. The difference $(\Delta)$ of circulating cortisol and cortisone before and after the reductive treatment. The ANOVA model with factor Gender followed by least significant difference multiple comparison was used. The symbols with error bars represent the group means with their $95 \%$ confidence intervals. $F$ is used for females, $\mathrm{M}$ for males. The significance of factors and interaction for $\Delta$ cortisol was as follows: Gender: $\mathrm{F}=0.1, \mathrm{p}=0.7346$; Age: $F=1.1, p=0.3729$; Gender $\times$ Age: $F=1.4, p=0.2335$ and for $\Delta$ cortisone it was: Gender: $F=0.7, p=0.4163$; Age: $F=0.9$, $p=0.4676$; Gender $\times$ Age: $F=0.4, p=0.8447$.

Among glucocorticoids (Fig. 2), we found significant reduction in levels of cortisone after the reductive treatment, whereas levels of cortisol remained without significant change.

Circulating levels of selected sex steroid were significantly decreased in the case of E2, while DHT levels remained unchanged after the reduction treatment (Fig. 3).

Interestingly, while changes in concentration of DHEA did not reach statistical significance, levels of its metabolites did vary before and after the treatment (Fig. 4). We found increasing levels of $7 \beta$-hydroxyDHEA, while the same tendency in the case of $7 \alpha$-hydroxy-DHEA was observed only in girls. 


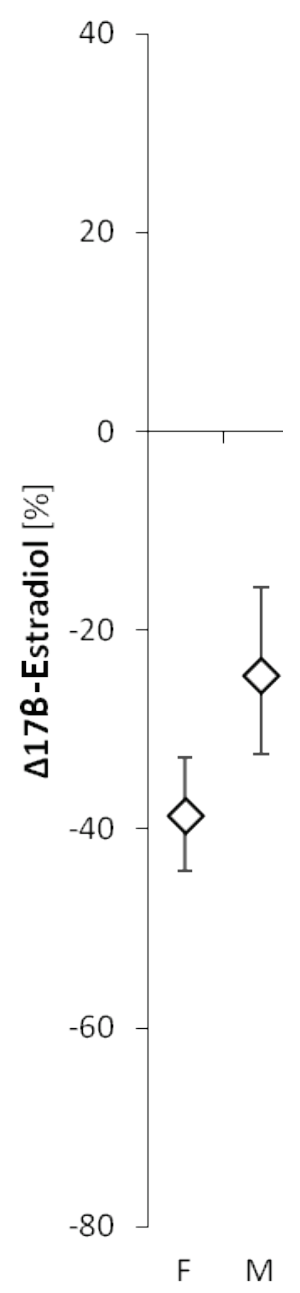

Gender

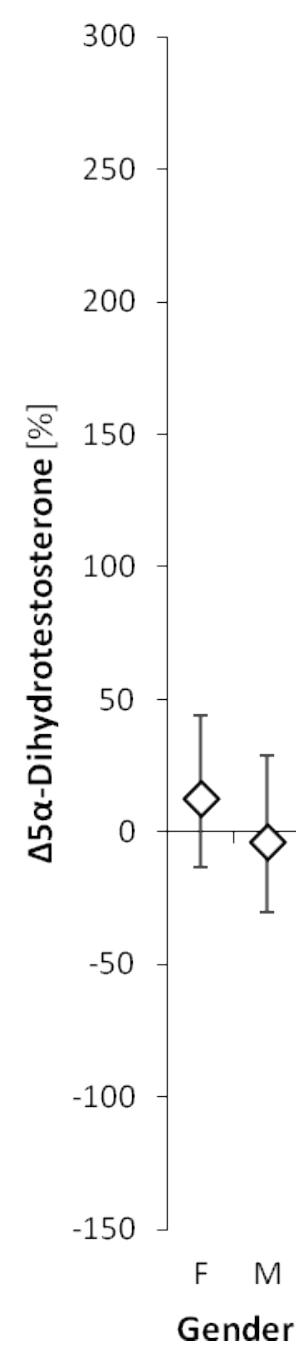

Fig. 3. The difference $(\Delta)$ of circulating $17 \beta$-estradiol and $5 a$-dihydrotestosterone before and after the reductive treatment. The ANOVA model with factor Gender group interaction followed by least significant difference multiple comparison was used. The symbols with error bars represent the group means with their $95 \%$ confidence intervals. $F$ is used for females, $M$ for males. The significance of factors and interaction for $\Delta 17 \beta$-estradiol was as follows: Gender: $F=4.1, p=0.0451 ;$ Age: $F=6.8, p<0.0001$; Gender $\times$ Age: $F=2.3, \quad p=0.0638$ and for $\Delta 5 a-$ dihydrotestosterone it was: and Gender: $F=0.3, p=0.5733$; Age: $\mathrm{F}=2.1, \mathrm{p}=0.0828$; Gender $\times$ Age: $\mathrm{F}=1, \mathrm{p}=0.4268$, respectively.

We followed ratios of hormones representing products/precursors to evaluate the activity of the enzyme. The cortisone/cortisol ratio, associated with the activity of the 11ß-HSD 1, was decreased after the treatment, but with statistical significance only in girls. The 7-oxo-DHEA/7 $\alpha$-hydroxy-DHEA ratio, also reflecting the activity of the $11 \beta-H S D 1$, was significantly decreased in boys. Moreover, the amount of $7 \alpha$-hydroxylation expressed as the $7 \alpha$-hydroxyDHEA/DHEA ratio was increased after the reductive therapy (Fig. 5).
Some of the measured parameters showed significance enabling treatment efficacy to be predicted. Using the OPLS method we explained $20.1 \%$ of variability of BMI, z-score change as the dependent variable. The strongest predictor among the examined steroids was the basal levels of $7 \alpha$-hydroxy-DHEA, followed by basal levels of DHEA, cortisol and E2 (Fig. 6).

\section{Discussion}

Our study gives an overview of changes in steroid hormone levels related to the enzyme $11 \beta$-HSD 1 , which occur during reduction treatment. Unlike other studies, we simultaneously examined circulating levels of glucocorticoids, metabolites of DHEA and other steroids known for their ability to modulate the activity of the enzyme 11ß-HSD 1.

Consistent with the majority of studies reviewed elsewhere (Seimon et al. 2013), we did not observe changes in cortisol levels. As far we know there are no data on impact of reductive therapy on the levels of serum cortisone or ratio cortisone/cortisol in juvenile obese patients.

In accordance with our expectations, we observed reduced levels of E2 after the treatment. Our finding was consistent with other studies performed mostly on females (Boyar et al. 1988, Heber et al. 1991, Campbell et al. 2012) or girls (Dorgan et al. 2003). Surprisingly, we did not prove significant differences in levels of DHT in the treated subjects, despite the other study that showed an increase of circulating DHT with decreasing BMI in men (Dušková et al. 2013). This discrepancy may be the result of the different gender and age of the examined cohorts.

As we reported in our preliminary study (Macova et al. 2014), circulating 7-hydroxy- and 7-oxoderivatives of DHEA change during the reductive treatment. In the present study, we observed similar results, although some parameters varied. First of all, these differences may be the result of the extension of recruited patients. Secondly, we used the novel advanced LC-MS/MS method, which is more sensitive and specific than immunoassays we used in previous study. Moreover, a different statistical approach was used to evaluate the measured data. Whereas in the previous study we calculated the absolute values of variables, in the present study the values were expressed as a percent of change measured after treatment. 


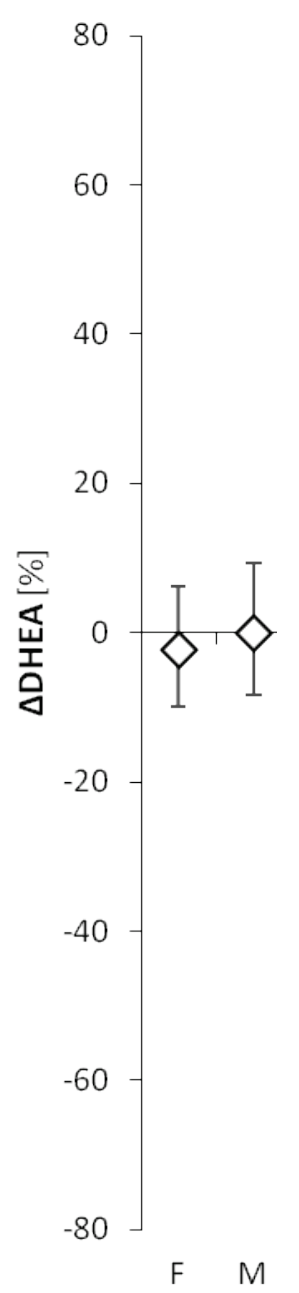

Gender

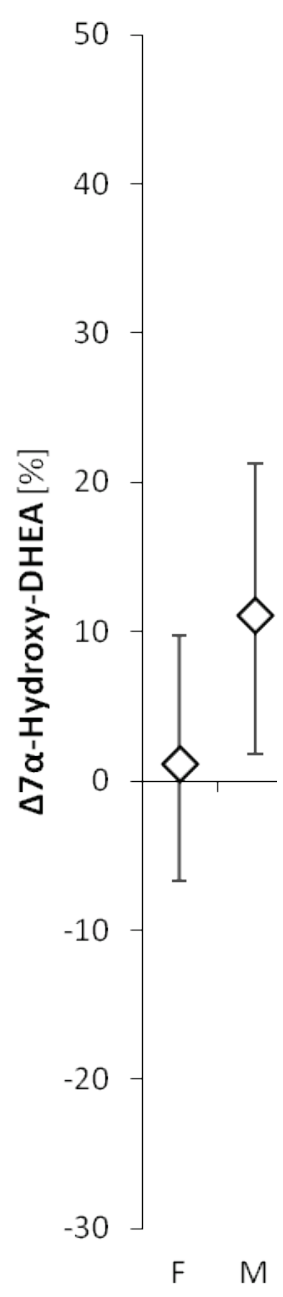

Gender

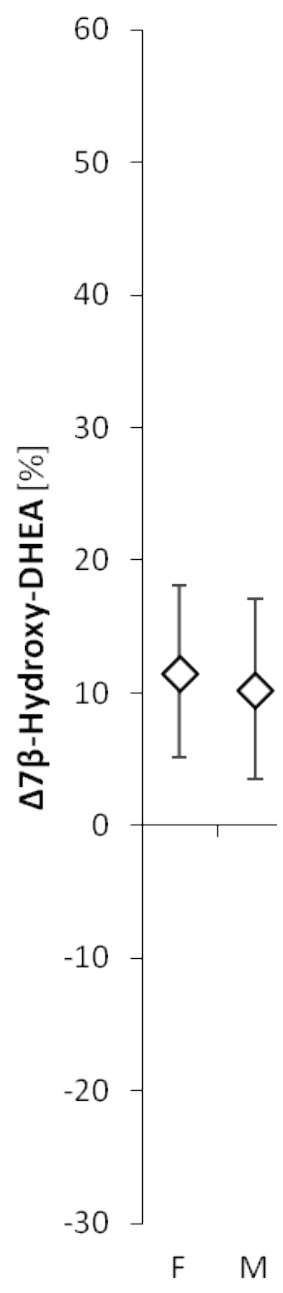

Gender

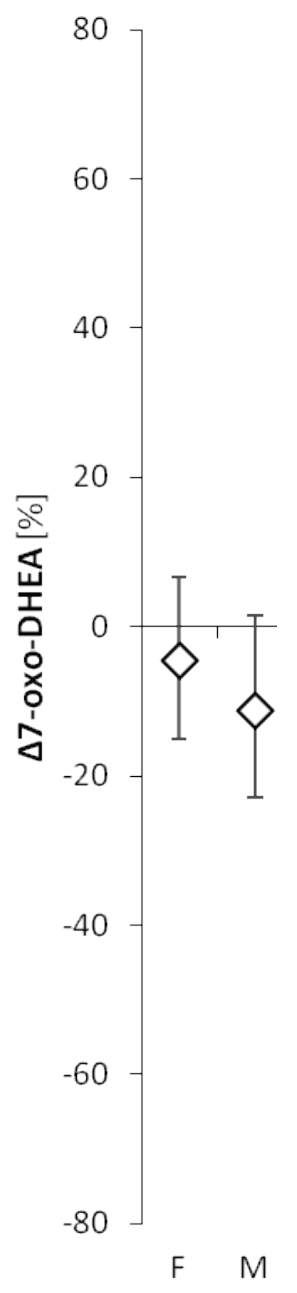

Gender

Fig. 4. The difference $(\Delta)$ of circulating dehydroepiandrosterone (DHEA), 7a-OH-DHEA, 7 $\beta-O H-D H E A$ and 7-oxo-DHEA before and after the reductive treatment. The ANOVA model with factor Gender group interaction followed by least significant difference multiple comparison was used. The symbols with error bars represent the group means with their $95 \%$ confidence intervals. $F$ is used for females, $M$ for males. The significance of factors and interaction for $\triangle D H E A$ was as follows: Gender: $F=0.1, p=0.7884 ; A g e: F=0.2$, $p=0.9391$; Gender $\times$ Age: $F=1.2, p=0.3073$, for 7a-hydroxy-DHEA it was Gender: $F=1.2, p=0.2759$; Age: $F=0.2, p=0.9538 ; G e n d e r \times$ Age: $F=0.5, p=0.738$, for $7 \beta$-hydroxy-DHEA it was Gender: $F=0, p=0.8474$; Age: $F=0.3, p=0.8641$; Gender $\times$ Age: $F=1.7, p=0.1617$, and for 7-oxo-DHEA it was Gender: $F=0.3, p=0.5733$; Age: $F=2.1, p=0.0828$; Gender $\times$ Age: $F=1, p=0.4268$, respectively.

In the present study, we observed significantly reduced 7-oxo/7 $\alpha$-hydroxy-DHEA ratio in boys and increased proportion of $7 \alpha$-hydroxylation expressed as increased 7 $\alpha$-hydroxy-DHEA/DHEA ratio in the examined cohort. Both observations support the hypothesis on DHEA metabolites involvement in metabolic processes and maintaining energy balance of the human body. Indeed, 7-oxo-DHEA has been reported as an "ergosteroid" with a thermoregulatory effect, which induces shift from oxidative metabolism towards increased heat production (Lardy et al. 1995) and, after transdermal administration, improves hormonal and lipid parameters (Sulcova et al. 2001). Although the significance of DHEA derivatives on human metabolism has not been fully elucidated, some drugs based on these compounds have already appeared on the market as antiobesity medication (www.dietspotlight.com/lean-xtremereview/).

According to our OPLS model, some of the examined parameters had significant power for BMI, z-score $\%$ change prediction. The amount of explained variability $(20.1 \%)$ is significant when taking into account that the model does not include parameters typically examined in obese patients (parameters of glucose and lipid metabolism or anthropometric variables such as waist circumference, body fat mass, skinfolds size, etc.). 


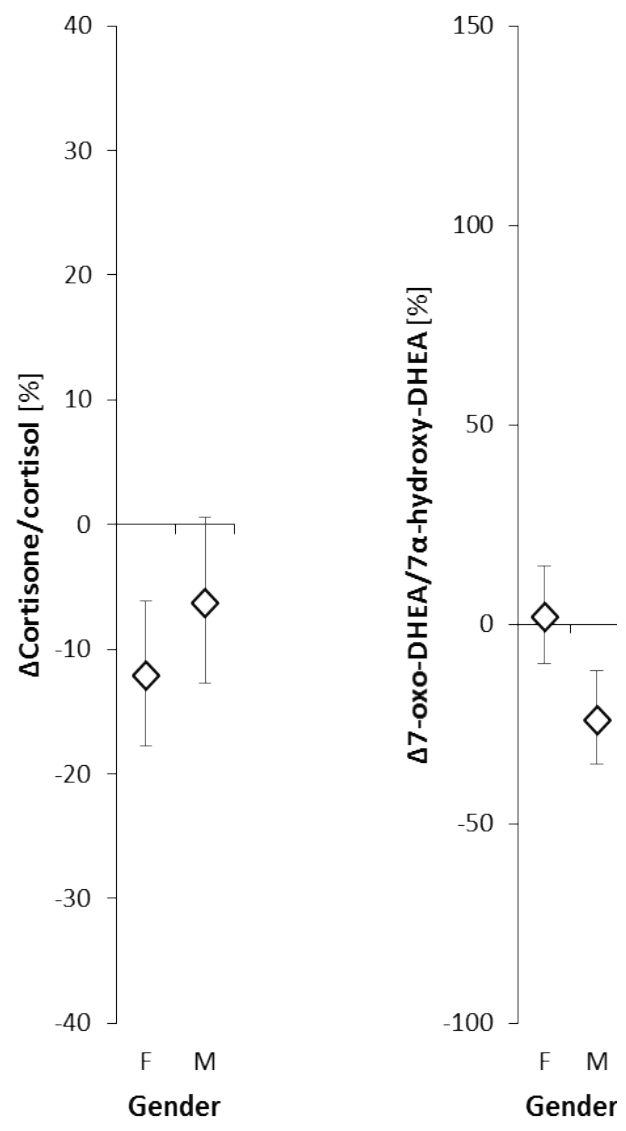

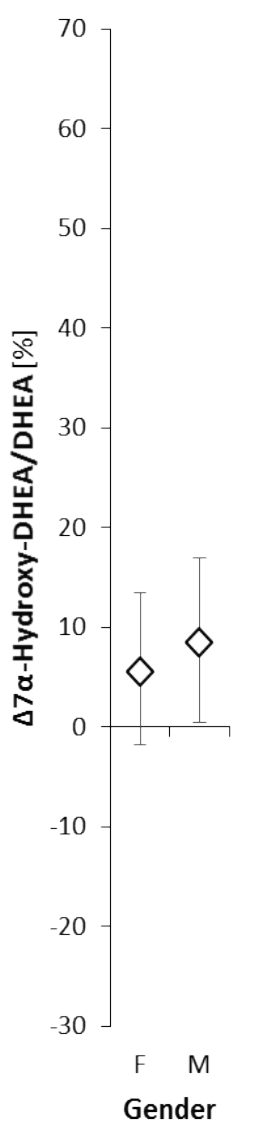

Fig. 5. The difference $(\Delta)$ of steroid ratios reflecting the activity of $11 \beta$-hydroxysteroid dehydrogenase type 1 and before and after the reductive treatment. The ANOVA model with factor Gender group interaction followed by least significant difference multiple comparison was used. The symbols with error bars represent the group means with their $95 \%$ confidence intervals. $F$ is used for females, $M$ for males. The significance of factors and interaction for $\Delta$ (Cortisone/cortisol) was Gender: $\mathrm{F}=0.9$, $\mathrm{p}=0.3538$; Age: $\mathrm{F}=1.5, \mathrm{p}=0.2002$; Gender $\times$ Age: $\mathrm{F}=1.2, \mathrm{p}=0.3367$; for $\Delta$ (7-oxo-DHEA/7ahydroxy-DHEA) it was Gender: $F=4.6$, $\mathrm{p}=0.0346$; Age: $\mathrm{F}=3.4, \mathrm{p}=0.0116$; Gender $\times$ Age: $F=2.5, p=0.044$, and for $\Delta$ (7a-hydroxyDHEA/DHEA) it was Gender: $F=0.1$, $p=0.7269$; Age: $F=0.6, p=0.6344$; Gender $x$ Age: $\mathrm{F}=2.1, \mathrm{p}=0.0807$, respectively.

\begin{tabular}{|c|c|c|c|c|}
\hline & \multirow[b]{2}{*}{ Variable } & \multicolumn{3}{|c|}{ Predictive component } \\
\hline & & 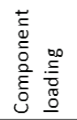 & 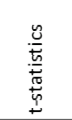 & \& \\
\hline \multirow{9}{*}{ 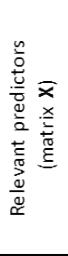 } & Age & 0.409 & 11.44 & $0.655^{*} *$ \\
\hline & BMI, z-score, basal & 0.299 & 7.01 & $0.480^{*}$ \\
\hline & $7 \alpha$-Hydroxy-DHEA, basal & 0.444 & 9.96 & $0.712 *$ \\
\hline & Cortisol, basal & 0.331 & 6.92 & $0.531 *$ \\
\hline & Estradiol, basal & 0.251 & 4.72 & $0.402^{*}$ \\
\hline & DHEA, basal & 0.405 & 10.77 & $0.648 *$ \\
\hline & $7 \beta$-Hydroxy-DHEA $7 \alpha$-Hydroxy-DHEA, basal & -0.394 & -10.17 & $-0.631 *$ \\
\hline & Cortisone $/{ }^{*}$ cortisol, basal & -0.382 & -6.98 & $-0.613 *$ \\
\hline & 7ß-Hydroxy-DHEA \%change & -0.178 & -2.48 & $-0.284 *$ \\
\hline
\end{tabular}

\section{Explained variability}

${ }^{a}$ R...Component lo dings expressed as a correlation coefficients with predictive component, ${ }^{*} p<0.05,{ }^{* *} p<0.01$

\section{$20.1 \%$ (16\% after cross-validation)}

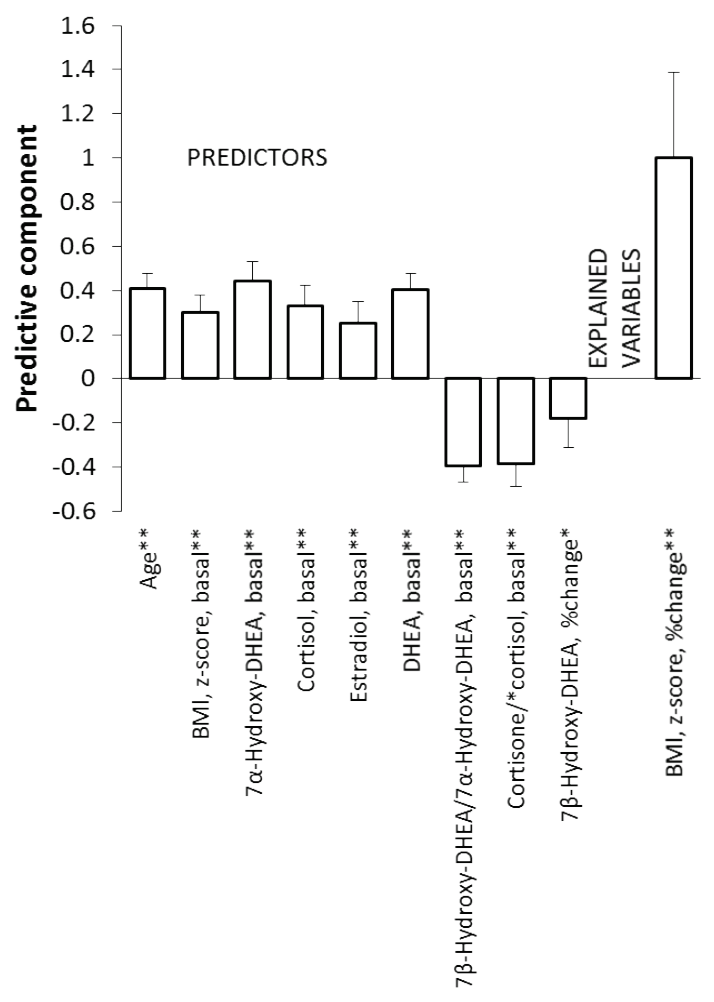

Fig. 6. Relationship between BMI, Z-score, \% change (matrix $Y$ ) and circulating steroids (matrix $X$ ), as evaluated by OPLS model (for details see Statistical analysis). T-statistic is a ratio of component loading and statistical error. BMI, body mass index; DHEA, dehydroepiandrosterone. 
Our results demonstrate diminished ratios of circulating steroids towards reduced metabolites (cortisol, 7-hydroxy-DHEA) after the weight reduction therapy. However, the interpretation of the result is quite intricate with regard to $11 \beta$-HSD 1 . Primarily, the enzyme activity of $11 \beta$-HSD 1 differs between tissues and, subsequently, the contribution of GC by various tissues into the circulation is different. In obese patients there has been suggested a mechanism of impaired reactivation of cortisone to cortisol by liver $11 \beta$-HSD 1 , which has been balanced by increased activity of $11 \beta$-HSD 1 in adipose tissue (Rask et al. 2001).

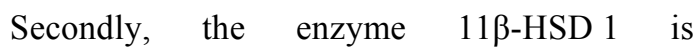
bidirectional. Although reductase activity predominates in vivo, converting cortisol to cortisone, under certain conditions, the enzyme switches towards dehydrogenase activity, which has been described, for example, in the process of adipocytes maturation (Bujalska et al. 2002). The directionality of $11 \beta$-HSD 1 is driven by pyridine nucleotide cofactor NADP+/NADPH redox potential, derived from hexose-6-phosphate dehydrogenase and co-localized with $11 \beta$-HSD 1 in endoplasmic reticulum lumen (White et al. 2007). NADPH favors reductase activity of $11 \beta$-HSD 1 , whereas the predominance of NADP + switches towards dehydrogenase activity (Zhou et al. 2012).

Moreover, there are other enzymes that regulate GC levels. The second type of isozyme $11 \beta$-HSD (11 -HSD 2) is expressed mainly in mineralocorticoid target tissues such as the kidney, colon and salivary glands (Shimojo et al. 1997). It converts cortisol to inactive cortisone in order to decrease local glucocorticoid levels, and thus protects mineralocorticoid receptors from cortisol activation. However, we do not expect that the changes described in our study were caused by changed activity of $11 \beta$-HSD 2, as similar levels of $11 \beta$-HSD 2 with different BMI were observed (Stewart et al. 1999).

The mechanism of GC regulation also involved $5 \alpha$-reductase, the enzyme responsible for the irreversible inactivation of cortisol leading towards waste metabolites excreted in the urine. Studies have reported the enhanced inactivation of cortisol by $5 \alpha$-reductase to be associated with obesity (Andrew et al. 1998) and, similarly, decreased activity of the enzyme after the weight loss was observed (Tomlinson et al. 2008). The same enzyme has the ability to metabolize testosterone to DHT. In our study, we did not examine levels of testosterone due to the generally accepted statement that testosterone is usually reduced in male obesity (Alvarez-Castro et al. 2011, De Maddalena et al. 2012). If we assume increased levels of testosterone (substrate) associated with lower BMI, our observation with no significant change of circulating DHT (product) is consistent with the hypothesis of reduced $5 \alpha$-reductase activity after the weight loss (Tomlinson et al. 2008).

It is likely that, due to the complexity of the mechanism regulating GC levels, even subtle changes in circulating steroids may induce dramatic changes on the whole-body level. Changes of steroid concentrations toward reduced forms that occur during the reduction treatment and that are presented in our study might be explained by following mechanism: In obese patients, local cortisol production increases, due to the increased activity of $11 \beta$-HSD 1 in adipose tissue. Although this cortisol production (obtained mostly from the subcutaneous adipose tissue) was estimated at approximately $10 \%$ of the whole body activity (Stimson et al. 2009), such an increase is enough to trigger mechanisms leading to compensation. The mechanism involves the reduction of $11 \beta$-HSD 1 in the liver and increase the activity of $5 \alpha$-reductase, both observed in obesity (Andrew et al. 1998, Rask et al. 2001). Moreover, the cortisol production rate by the liver has been estimated to be at least equivalent to that of the adrenal gland in a healthy population (Stimson and Walker 2013). The changes in GC metabolism that arise from hepatic $11 \beta$-HSD 1 reduction predict lower plasma levels, which could explain the compensatory increase in the activity of hypothalamic-pituitaryadrenal axis found in obese patients (Pasquali et al. 1996).

Therefore, if calorie restriction and fat loss causes reduction in cortisol production in adipose tissue, it may be compensated by increased reductase activity of $11 \beta$-HSD 1 in the liver to maintain cortisol levels balanced. Considering the prevailing contribution of hepatic 11 $\beta$-HSD 1 to extra-adrenal cortisol regeneration, we speculate that the changes in circulating cortisone levels we observed after the reductive treatment may be due to the increased activity of hepatic 11 $\beta$-HSD 1. Follow-up studies regarding hepatic activity of $11 \beta$-HSD 1 are necessary to confirm our suspicion.

In summary, we have found reduced circulating levels of cortisone and reduced ratios of oxygenated/ reduced metabolites after the reductive treatment in 
juvenile obese patients. Moreover, DHEA and its 7-hydroxylated metabolites showed significance to the prediction of reductive treatment efficacy. Our findings support a role of $11 \beta$-HSD 1 as well as derivatives of DHEA in the control of human metabolism. However, further studies are needed to determine whether the observed changes can be attributed to the altered activity of the liver $11 \beta$-HSD 1.

\section{Conflict of Interest}

There is no conflict of interest.

\section{Acknowledgements}

The study was supported by the grant NT/13542-3 Internal Grant Agency of the Czech Ministry of Health.

\begin{abstract}
Abbreviations
$11 \beta$-HSD 1, 11 -hydroxysteroid dehydrogenase type 1; BMI, body mass index; DHEA, dehydroepiandrosterone; DHT, 5 $\alpha$-dihydrotestosterone; E2, 17 $\beta$-estradiol; GC, glucocorticoids; LC-MS/MS, liquid chromatographytandem mass spectrometry; OPLS, orthogonal projections to latent structures; RIA, radioimmunoassay.
\end{abstract}

\section{References}

ABRAHAM SB, RUBINO D, SINAII N, RAMSEY S, NIEMAN LK: Cortisol, obesity, and the metabolic syndrome: a cross-sectional study of obese subjects and review of the literature. Obesity (Silver Spring) 21: E105-E117, 2013.

ALVAREZ-CASTRO P, SANGIAO-ALVARELLOS S, BRANDON-SANDA I, CORDIDO F: Endocrine function in obesity (in Spanish). Endocrinol Nutr 58: 422-432, 2011.

ANAGNOSTIS P, KATSIKI N, ADAMIDOU F, ATHYROS VG, KARAGIANNIS A, KITA M, MIKHAILIDIS DP: 11 beta-hydroxysteroid dehydrogenase type 1 inhibitors: novel agents for the treatment of metabolic syndrome and obesity-related disorders? Metabolism 62: 21-33, 2013.

ANDERSSON T, SODERSTROM I, SIMONYTE K, OLSSON T: Estrogen reduces 11beta-hydroxysteroid dehydrogenase type 1 in liver and visceral, but not subcutaneous, adipose tissue in rats. Obesity (Silver Spring) 18: 470-475, 2010.

ANDREW R, PHILLIPS DI, WALKER BR: Obesity and gender influence cortisol secretion and metabolism in man. J Clin Endocrinol Metab 83: 1806-1809, 1998.

APOSTOLOVA G, SCHWEIZER RA, BALAZS Z, KOSTADINOVA RM, ODERMATT A: Dehydroepiandrosterone inhibits the amplification of glucocorticoid action in adipose tissue. Am J Physiol 288: E957-E964, 2005.

BISTA B, BECK N: Cushing syndrome. Indian J Pediatr 81: 158-164, 2014.

BOYAR AP, ROSE DP, LOUGHRIDGE JR, ENGLE A, PALGI A, LAAKSO K, KINNE D, WYNDER EL: Response to a diet low in total fat in women with postmenopausal breast cancer: a pilot study. Nutr Cancer 11: 93-99, 1988 .

BUJALSKA IJ, WALKER EA, HEWISON M, STEWART PM: A switch in dehydrogenase to reductase activity of 11 beta-hydroxysteroid dehydrogenase type 1 upon differentiation of human omental adipose stromal cells. $J$ Clin Endocrinol Metab 87: 1205-1210, 2002.

BUJALSKA IJ, QUINKLER M, TOMLINSON JW, MONTAGUE CT, SMITH DM, STEWART PM: Expression profiling of 11beta-hydroxysteroid dehydrogenase type-1 and glucocorticoid-target genes in subcutaneous and omental human preadipocytes. J Mol Endocrinol 37: 327-340, 2006.

CAMPBELL KL, FOSTER-SCHUBERT KE, ALFANO CM, WANG CC, WANG CY, DUGGAN CR, MASON C, IMAYAMA I, KONG A, XIAO L, BAIN CE, BLACKBURN GL, STANCZYK FZ, MCTIERNAN A: Reduced-calorie dietary weight loss, exercise, and sex hormones in postmenopausal women: randomized controlled trial. J Clin Oncol 30: 2314-2326, 2012.

CHMIELEWSKI V, DRUPT F, MORFIN R: Dexamethasone-induced apoptosis of mouse thymocytes: prevention by native 7alpha-hydroxysteroids. Immunol Cell Biol 78: 238-246, 2000.

DE MADDALENA C, VODO S, PETRONI A, ALOISI AM: Impact of testosterone on body fat composition. $J$ Cell Physiol 227: 3744-3748, 2012. 
DIEUDONNE MN, SAMMARI A, DOS SANTOS E, LENEVEU MC, GIUDICELLI Y, PECQUERY R: Sex steroids and leptin regulate 11beta-hydroxysteroid dehydrogenase I and P450 aromatase expressions in human preadipocytes: Sex specificities. J Steroid Biochem Mol Biol 99: 189-196, 2006.

DJURHUUS CB, GRAVHOLT CH, NIELSEN S, MENGEL A, CHRISTIANSEN JS, SCHMITZ OE, MOLLER N: Effects of cortisol on lipolysis and regional interstitial glycerol levels in humans. Am J Physiol Endocrinol Metab 283: E172-E177, 2002.

DORGAN JF, HUNSBERGER SA, MCMAHON RP, KWITEROVICH PO JR, LAUER RM, VAN HORN L, LASSER NL, STEVENS VJ, FRIEDMAN LA, YANOVSKI JA, GREENHUT SF, CHANDLER DW, FRANKLIN FA, BARTON BA, BUCKMAN DW, SNETSELAAR LG, PATTERSON BH, SCHATZKIN A, TAYLOR PR: Diet and sex hormones in girls: findings from a randomized controlled clinical trial. $J$ Natl Cancer Inst 95: 132-141, 2003.

DUŠKOVÁ M, POSPÍŠILOVÁ H, HILL M, STÁRKA L: Obesity, circulating androgens and their precursors. J Steroids Horm Sci 4: 2, 2013.

FEIG PU, SHAH S, HERMANOWSKI-VOSATKA A, PLOTKIN D, SPRINGER MS, DONAHUE S, THACH C, KLEIN EJ, LAI E, KAUFMAN KD: Effects of an 11 beta-hydroxysteroid dehydrogenase type 1 inhibitor, MK-0916, in patients with type 2 diabetes mellitus and metabolic syndrome. Diabetes Obes Metab 13: 498-504, 2011.

GIBBS JP, EMERY MG, MCCAFFERY I, SMITH B, GIBBS MA, AKRAMI A, ROSSI J, PAWELETZ K, GASTONGUAY MR, BAUTISTA E, WANG M, PERFETTI R, DANIELS O: Population pharmacokinetic/pharmacodynamic model of subcutaneous adipose 11beta-hydroxysteroid dehydrogenase type 1 (11beta-HSD1) activity after oral administration of AMG 221, a selective 11beta-HSD1 inhibitor. J Clin Pharmacol 51: 830-841, 2011.

GOMEZ-SANCHEZ EP, GANJAM V, CHEN YJ, LIU Y, ZHOU MY, TOROSLU C, ROMERO DG, HUGHSON MD, DE RODRIGUEZ A, GOMEZ-SANCHEZ CE: Regulation of 11 beta-hydroxysteroid dehydrogenase enzymes in the rat kidney by estradiol. Am J Physiol Endocrinol Metab 285: E272-E279, 2003.

HAMMAMI MM, SIITERI PK: Regulation of 11 beta-hydroxysteroid dehydrogenase activity in human skin fibroblasts: enzymatic modulation of glucocorticoid action. J Clin Endocrinol Metab 73: 326-334, 1991.

HAMPL R, PUTZ Z, STARKA L: Radioimmunological determination of dihydrotestosterone and its value in laboratory diagnosis. Biochem Clin Bohemoslov 19: 157-163, 1990.

HAUNER H, SCHMID P, PFEIFFER EF: Glucocorticoids and insulin promote the differentiation of human adipocyte precursor cells into fat cells. J Clin Endocrinol Metab 64: 832-835, 1987.

HEBER D, ASHLEY JM, LEAF DA, BARNARD RJ: Reduction of serum estradiol in postmenopausal women given free access to low-fat high-carbohydrate diet. Nutrition 7: 137-139; discussion 139-140, 1991.

HEISE T, MORROW L, HOMPESCH M, HARING HU, KAPITZA C, ABT M, RAMSAUER M, MAGNONE MC, FUERST-RECKTENWALD S: Safety, efficacy and weight effect of two 11beta-HSD1 inhibitors in metformin-treated patients with type 2 diabetes. Diabetes Obes Metab 16: 1070-1077, 2014.

HENNEBERT O, CHALBOT S, ALRAN S, MORFIN R: Dehydroepiandrosterone 7alpha-hydroxylation in human tissues: possible interference with type 111 beta-hydroxysteroid dehydrogenase-mediated processes. J Steroid Biochem Mol Biol 104: 326-333, 2007.

HLAVATY P, ZAMRAZILOVA H, KUNESOVA M, DUSATKOVA L, SEDLACKOVA B, HAINER V: Reduction of abdominal obesity and cardiometabolic health risks in obese adolescents in response to a short-term spa weight management program (in Czech). Cas Lek Cesk 149: 537-541, 2010.

KANNISTO K, PIETILAINEN KH, EHRENBORG E, RISSANEN A, KAPRIO J, HAMSTEN A, YKI-JARVINEN $\mathrm{H}$ : Overexpression of 11 beta-hydroxysteroid dehydrogenase- 1 in adipose tissue is associated with acquired obesity and features of insulin resistance: studies in young adult monozygotic twins. $J$ Clin Endocrinol Metab 89: 4414-4421, 2004.

KOBZOVA J, VIGNEROVA J, BLAHA P, KREJCOVSKY L, RIEDLOVA J: The 6th nationwide anthropological survey of children and adolescents in the Czech Republic in 2001. Cent Eur J Public Health 12: 126-130, 2004. 
KOTELEVTSEV Y, HOLMES MC, BURCHELL A, HOUSTON PM, SCHMOLL D, JAMIESON P, BEST R, BROWN R, EDWARDS CR, SECKL JR, MULLINS JJ: 11beta-hydroxysteroid dehydrogenase type 1 knockout mice show attenuated glucocorticoid-inducible responses and resist hyperglycemia on obesity or stress. Proc Natl Acad Sci USA 94: 14924-14929, 1997.

LARDY H, PARTRIDGE B, KNEER N, WEI Y: Ergosteroids: induction of thermogenic enzymes in liver of rats treated with steroids derived from dehydroepiandrosterone. Proc Natl Acad Sci USA 92: 6617-6619, 1995.

LIU YJ, NAKAGAWA Y, TOYA K, SAEGUSA H, NASUDA K, ENDOH A, OHZEKI T: Effects of thyroid hormone (thyroxine) and testosterone on hepatic 11beta-hydroxysteroid dehydrogenase mRNA and activity in pubertal hypothyroid male rats. Metabolism 47: 474-477, 1998.

LIVINGSTONE DE, JONES GC, SMITH K, JAMIESON PM, ANDREW R, KENYON CJ, WALKER BR: Understanding the role of glucocorticoids in obesity: tissue-specific alterations of corticosterone metabolism in obese Zucker rats. Endocrinology 141: 560-563, 2000.

MACOVA L, BICIKOVA M, ZAMRAZILOVA H, HILL M, KAZIHNITKOVA H, SEDLACKOVA B, STARKA L: Reduced levels of circulating 7alpha-hydroxy-dehydroepiandrosterone in treated adolescent obese patients. Physiol Res 63: 95-101, 2014.

MASUZAKI H, PATERSON J, SHINYAMA H, MORTON NM, MULLINS JJ, SECKL JR, FLIER JS: A transgenic model of visceral obesity and the metabolic syndrome. Science 294: 2166-2170, 2001.

MORTON NM, HOLMES MC, FIEVET C, STAELS B, TAILLEUX A, MULLINS JJ, SECKL JR: Improved lipid and lipoprotein profile, hepatic insulin sensitivity, and glucose tolerance in 11 beta-hydroxysteroid dehydrogenase type 1 null mice. J Biol Chem 276: 41293-41300, 2001.

MULLER C, HENNEBERT O, MORFIN R: The native anti-glucocorticoid paradigm. J Steroid Biochem Mol Biol 100: 95-105, 2006a.

MULLER C, POMPON D, URBAN P, MORFIN R: Inter-conversion of 7alpha- and 7beta-hydroxydehydroepiandrosterone by the human 11 beta-hydroxysteroid dehydrogenase type 1. J Steroid Biochem Mol Biol 99: 215-222, 2006b.

PASQUALI R, ANCONETANI B, CHATTAT R, BISCOTTI M, SPINUCCI G, CASIMIRRI F, VICENNATI V, CARCELLO A, LABATE AM: Hypothalamic-pituitary-adrenal axis activity and its relationship to the autonomic nervous system in women with visceral and subcutaneous obesity: effects of the corticotropinreleasing factor/arginine-vasopressin test and of stress. Metabolism 5: 351-356, 1996.

RASK E, OLSSON T, SODERBERG S, ANDREW R, LIVINGSTONE DE, JOHNSON O, WALKER BR: Tissuespecific dysregulation of cortisol metabolism in human obesity. J Clin Endocrinol Metab 86: 1418-1421, 2001.

RASK E, WALKER BR, SODERBERG S, LIVINGSTONE DE, ELIASSON M, JOHNSON O, ANDREW R, OLSSON T: Tissue-specific changes in peripheral cortisol metabolism in obese women: increased adipose 11 beta-hydroxysteroid dehydrogenase type 1 activity. J Clin Endocrinol Metab 87: 3330-3336, 2002.

REBUFFE-SCRIVE M, KROTKIEWSKI M, ELFVERSON J, BJORNTORP P: Muscle and adipose tissue morphology and metabolism in Cushing's syndrome. J Clin Endocrinol Metab 67: 1122-1128, 1988.

RICKETTS ML, VERHAEG JM, BUJALSKA I, HOWIE AJ, RAINEY WE, STEWART PM: Immunohistochemical localization of type 111 beta-hydroxysteroid dehydrogenase in human tissues. $J$ Clin Endocrinol Metab 83: 1325-1335, 1998.

ROBINZON B, MICHAEL KK, RIPP SL, WINTERS SJ, PROUGH RA: Glucocorticoids inhibit interconversion of 7-hydroxy and 7-oxo metabolites of dehydroepiandrosterone: a role for 11beta-hydroxysteroid dehydrogenases? Arch Biochem Biophys 412: 251-258, 2003.

ROSENSTOCK J, BANARER S, FONSECA VA, INZUCCHI SE, SUN W, YAO W, HOLLIS G, FLORES R, LEVY R, WILLIAMS WV, SECKL JR, HUBER R, INVESTIGATORS IP: The 11-beta-hydroxysteroid dehydrogenase type 1 inhibitor INCB13739 improves hyperglycemia in patients with type 2 diabetes inadequately controlled by metformin monotherapy. Diabetes Care 33: 1516-1522, 2010.

ROSMOND R: Role of stress in the pathogenesis of the metabolic syndrome. Psychoneuroendocrinology 30: 1-10, 2005.

SCHACKE H, DOCKE WD, ASADULLAH K: Mechanisms involved in the side effects of glucocorticoids. Pharmacol Ther 96: 23-43, 2002. 
SECKL JR, WALKER BR: Minireview: 11beta-hydroxysteroid dehydrogenase type 1- a tissue-specific amplifier of glucocorticoid action. Endocrinology 142: 1371-1376, 2001.

SEIMON RV, HOSTLAND N, SILVEIRA SL, GIBSON AA, SAINSBURY A: Effects of energy restriction on activity of the hypothalamo-pituitary-adrenal axis in obese humans and rodents: implications for diet-induced changes in body composition. Horm Mol Biol Clin Investig 15: 71-80, 2013.

SHAH S, HERMANOWSKI-VOSATKA A, GIBSON K, RUCK RA, JIA G, ZHANG J, HWANG PM, RYAN NW, LANGDON RB, FEIG PU: Efficacy and safety of the selective 11beta-HSD-1 inhibitors MK-0736 and MK-0916 in overweight and obese patients with hypertension. J Am Soc Hypertens 5: 166-176, 2011.

SHIMOJO M, RICKETTS ML, PETRELLI MD, MORADI P, JOHNSON GD, BRADWELL AR, HEWISON M, HOWIE AJ, STEWART PM: Immunodetection of 11 beta-hydroxysteroid dehydrogenase type 2 in human mineralocorticoid target tissues: evidence for nuclear localization. Endocrinology 138: 1305-1311, 1997.

SOSVOROVA L, VITKU J, CHLUPACOVA T, MOHAPL M, HAMPL R: Determination of seven selected neuro- and immunomodulatory steroids in human cerebrospinal fluid and plasma using LC-MS/MS. Steroids 98: 1-8, 2015.

STARKA L, HAMPL R: Die Isolation des 7 $\alpha$-Hydroxdehydroepiandrosterone Sulphates aus dem menschlichen Plasma. Naturwiss 51: 164-165, 1964.

STARKA L, SULCOVA J, SILINK K: Die Harnausscheidung des 7-Hydroxydehydroepi- androsteronsulfats. Clin Chim Acta 7: 309-316, 1962.

STEWART PM, BOULTON A, KUMAR S, CLARK PM, SHACKLETON CH: Cortisol metabolism in human obesity: impaired cortisone-->cortisol conversion in subjects with central adiposity. J Clin Endocrinol Metab 84: 1022$1027,1999$.

STIMSON RH, WALKER BR: The role and regulation of 11 beta-hydroxysteroid dehydrogenase type 1 in obesity and the metabolic syndrome. Horm Mol Biol Clin Investig 15: 37-48, 2013.

STIMSON RH, ANDERSSON J, ANDREW R, REDHEAD DN, KARPE F, HAYES PC, OLSSON T, WALKER BR: Cortisol release from adipose tissue by 11 beta-hydroxysteroid dehydrogenase type 1 in humans. Diabetes $\mathbf{5 8}$ : 46-53, 2009.

SUlCOVA J, HILL M, MASEK Z, CESKA R, NOVACEK A, HAMPL R, STARKA L: Effects of transdermal application of 7-oxo-DHEA on the levels of steroid hormones, gonadotropins and lipids in healthy men. Physiol Res 50: 9-18, 2001.

TAGAWA N, YUDA R, KUBOTA S, WAKABAYASHI M, YAMAGUCHI Y, KIYONAGA D, MORI N, MINAMITANI E, MASUZAKI H, KOBAYASHI Y: 17Beta-estradiol inhibits 11beta-hydroxysteroid dehydrogenase type 1 activity in rodent adipocytes. $J$ Endocrinol 202: 131-139, 2009.

TAGAWA N, MINAMITANI E, YAMAGUCHI Y, KOBAYASHI Y: Alternative mechanism for anti-obesity effect of dehydroepiandrosterone: possible contribution of 11 beta-hydroxysteroid dehydrogenase type 1 inhibition in rodent adipose tissue. Steroids 76: 1546-1553, 2011.

TOMLINSON JW, SINHA B, BUJALSKA I, HEWISON M, STEWART PM: Expression of 11beta-hydroxysteroid dehydrogenase type 1 in adipose tissue is not increased in human obesity. J Clin Endocrinol Metab 87: 5630$5635,2002$.

TOMLINSON JW, SHERLOCK M, HUGHES B, HUGHES SV, KILVINGTON F, BARTLETT W, COURTNEY R, REJTO P, CARLEY W, STEWART PM: Inhibition of 11beta-hydroxysteroid dehydrogenase type 1 activity in vivo limits glucocorticoid exposure to human adipose tissue and decreases lipolysis. J Clin Endocrinol Metab 92: 857-864, 2007.

TOMLINSON JW, FINNEY J, HUGHES BA, HUGHES SV, STEWART PM: Reduced glucocorticoid production rate, decreased 5alpha-reductase activity, and adipose tissue insulin sensitization after weight loss. Diabetes 57: 1536-1543, 2008.

VALSAMAKIS G, ANWAR A, TOMLINSON JW, SHACKLETON CH, MCTERNAN PG, CHETTY R, WOOD PJ, BANERJEE AK, HOLDER G, BARNETT AH, STEWART PM, KUMAR S: 11beta-hydroxysteroid dehydrogenase type 1 activity in lean and obese males with type 2 diabetes mellitus. J Clin Endocrinol Metab 89: 4755-4761, 2004. 
WHITE PC, ROGOFF D, MCMILLAN DR, LAVERY GG: Hexose 6-phosphate dehydrogenase (H6PD) and corticosteroid metabolism. Mol Cell Endocrinol 265-266: 89-92, 2007.

www.dietspotlight.com/lean-xtreme-review/

ZHOU HY, HU GX, LIAN QQ, MORRIS D, GE RS: The metabolism of steroids, toxins and drugs by 11 betahydroxysteroid dehydrogenase 1. Toxicology 292: 1-12, 2012.

ZHU L, HOU M, SUN B, BUREN J, ZHANG L, YI J, HERNELL O, LI X: Testosterone stimulates adipose tissue 11beta-hydroxysteroid dehydrogenase type 1 expression in a depot-specific manner in children. $J$ Clin Endocrinol Metab 95: 3300-3308, 2010. 